\title{
A Case of COVID-19 Patient Presenting with Gastrointestinal-Specific Symptoms in Indonesia
}

\author{
Daniel Martin Simadibrata*, Cleopas Martin Rumende ${ }^{* *}$,Rahmad Mulyadi***, \\ Marcellus Simadibrata**** \\ * Faculty of Medicine, Universitas Indonesia/Dr. Cipto Mangunkusumo General National Hospital \\ Jakarta \\ ** Division of Respirology and Critical Care, Department of Internal Medicine, Faculty of Medicine \\ Universitas Indonesia/Dr Cipto Mangunkusumo General National Hospital, Jakarta \\ *** Department of Radiology, Faculty of Medicine, Universitas Indonesia/Dr. Cipto Mangunkusumo \\ National General Hospital, Jakarta \\ **** Division of Gastroenterology, Department of Internal Medicine, Faculty of Medicine \\ Universitas Indonesia/Dr. Cipto Mangunkusumo General National Hospital, Jakarta
}

\section{Corresponding author:}

Cleopas Martin Rumende. Division of Respirology and Critical Care, Department of Internal Medicine, Dr. Cipto Mangunkusumo General National Hospital. Jl. Diponegoro No. 71 Jakarta Indonesia. Phone: +62-21-314 9704; facsimile: +62-21-31902461. E-mail: cleopas.martin@ui.ac.id

\begin{abstract}
Coronavirus disease 2019 (COVID-19) is an emerging infectious disease officially declared as a pandemic on 11 March 2020 by the World Health Organization (WHO). Indonesia's COVID-19 case fatality rate remain consistently high, approximately twice the global case fatality rate available. Patients typically present with fever, dry cough and dyspnea. However, there were reports of atypical COVID-19 symptoms such as myalgia, fatigue, diarrhea, nausea, and vomiting. These atypical presentations were suggested to indicate a more severe COVID-19. Here, we present a case of COVID-19 patient presenting with gastrointestinal-specific symptoms in Indonesia.
\end{abstract}

Keywords: COVID-19, coronavirus disease, gastrointestinal symptoms, Indonesia

\section{ABSTRAK}

Penyakit Coronavirus 2019 (COVID-19) adalah penyakit menular yang pada 11 Maret 2020 secara resmi dinyatakan sebagai pandemi oleh World Health Organization (WHO). Angka fatalitas kasus COVID-19 di Indonesia secara konsisten tetap tinggi, sekitar dua kali angka fatalitas kasus secara global yang ada. Pasien biasanya mengalami demam, batuk kering dan dispnea. Namun, ada laporan gejala COVID-19 yang atipikal seperti mialgia, kelelahan, diare, mual, dan muntah. Presentasi atipikal ini diusulkansebagai salah satu khas penyakit COVID-19 yang lebih parah. Di sini, kami menyajikan kasus pasien COVID-19 yang datang dengan gejala spesifik gastrointestinal di Indonesia.

Kata kunci: COVID-19, Penyakit coronavirus, gejala gastrointestinal, Indonesia 


\section{INTRODUCTION}

Recently, a new type of coronavirus, the 2019 novel Coronavirus (2019-nCoV), was identified by the World Health Organisation (WHO) known to cause an emerging infectious disease known as Coronavirus Disease 2019 (COVID-19). COVID-19 was officially declared a pandemic on the $11^{\text {th }}$ of March $2020^{1}$. As of March 29, 2020, the total number of COVID-19 cases was 509,164 worldwide with 156,602 of which had recovered; and a $4.76 \%$ case fatality (mortality) globally. The first cases of COVID-19-positive patient found in Indonesia was officially announced on March 2, 2020, which contracted from a foreigner positive with Covid-19. More concerning, Indonesia's case fatality rate is consistently high, within a range of $8-9 \%$, which accounts for twice the global case fatality rates available.

Patients with COVID-19 typically presents with fever $\left(>37.3^{\circ} \mathrm{C}\right)$, dry cough, and dyspnea, but studies have also reported other clinical characteristics, such as myalgia, fatigue, diarrhea, nausea or vomiting ${ }^{2}$. Presentation of atypical COVID-19 infection has been speculated to indicate a more severe form of the disease. Involvement of gastrointestinal-specific symptoms have been found, however in very low number of COVID-19 patients ${ }^{2-4}$. Similarly, the first confirmed case of COVID-19 infection in the United States also reported a 2-day history of nausea and vomiting on admission 5 . Here, we report a case of confirmed COVID-19 patients presenting with gastrointestinal-specific symptoms.

\section{CASE ILLUSTRATION}

The patient was a 54-year-old male with a known history of Type II Diabetes mellitus and chronic hypertensionwho came to a 24-Hour Executive Clinic in Cipto Mangunkusumo Hospital on March 8, 2020. The patient presented with a chief complaint of 2-day history of nausea and vomiting after every meal. Patient experienced fever and productive cough with clear sputum which started 6 days before administration. The fever subsided and temperature returned normal after given over-the-counter (OTC) antipyretic. On admission, the patient complained of epigastric pain with a visual analog scale (VAS) of 3 (out of 10) that worsen with time and subsidedwhen the patient rested. The patient denied any shortness of breath and travel history to countries with emerging cases of COVID-19. The patient had no history of allergy but had a history of Type II Diabetes Mellitus and chronic hypertension and routinely consumed amlodipine $5 \mathrm{mg}$ once daily, candesartan $8 \mathrm{mg}$ once daily, linagliptin/metformin $\mathrm{HCl}$ (Trajenta Duo) $2.5 \mathrm{mg} / 850 \mathrm{mg}$ twice daily. All other history was unremarkable.

On arrival to the hospital, the patient was alert and looked well. Physical examination revealed a body temperature of $37.4^{\circ} \mathrm{C}$, blood pressure of $157 / 94 \mathrm{~mm}$ $\mathrm{Hg}$, respiratory rate of 18 breaths per minute, pulse of 95 beats per minute, and oxygen saturation of $96 \%$ while the patient was breathing ambient air. The patient was $179 \mathrm{~cm}$ tall and weighed $82 \mathrm{~kg}$. On respiratory examination, there were crackles on auscultation on all regions of the lung. Abdominal examination showed epigastric pain upon palpation. All other physical examination results were unremarkable.

Ultrasound examination of the liver showed the patients had fatty liver disease (Figure 1). Chest radiology examination of the lungs showed opacity at the lower lobe of the right lung (Figure 2).Blood laboratory results showed anemia, with an elevated aspartate aminotransferase (AST), slightly elevated blood ureum and creatine with decreased eGFR, elevated random blood glucose, and hyponatremia and hypochloremia (Table 1). Urinalysis results

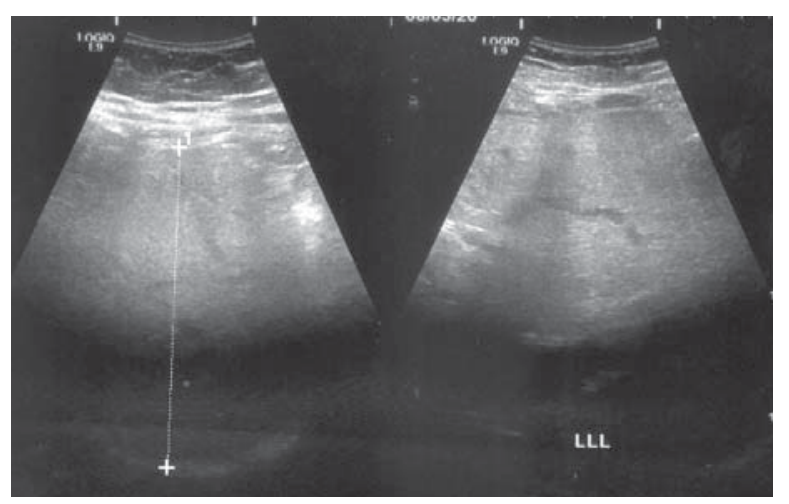

Figure 1. Ultrasound image of the liver (08/03/2020)

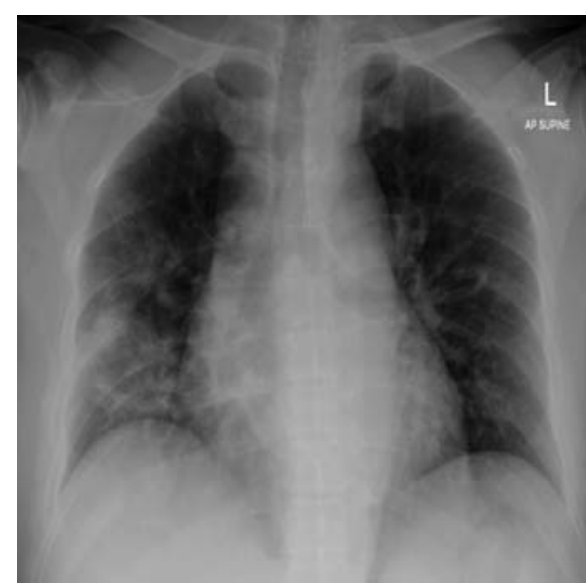

Figure 2. Chest radiography showing opacity at the lower lobe of the right lung $(08 / 03 / 2020)$ 
reported an increase in erythrocyte found in the urine as well as albuminuria. Other laboratory results were unremarkable.

Therefore, the initial working diagnosis was Virallike pneumonia, dyspepsia, type II Diabetes mellitus with signs of nephropathy (renal insufficiency), grade I hypertension, fatty liver, grade I obesity. The patient was admitted as inpatient and immediately given intravenous ringer acetate $500 \mathrm{~mL}$ for 8 hours, ondansetron 8mg IV and paracetamol $1000 \mathrm{mg}$ IV.

The patients treatment regiments were symptomatic and included pantoprazole (Pantozol) $40 \mathrm{mg}$ IV once daily, ondansetron (Narfoz) $8 \mathrm{mg}$ IV three times daily, domperidone (Vometa) $10 \mathrm{mg}$ tablet three times daily, meropenem (Meronem) 1000mg IV twice daily, levofloxacin (Cravit) $750 \mathrm{mg}$ IV once daily, N-acetylcysteine (Fluimucil) $200 \mathrm{mg}$ capsule three times daily, and paracetamol (Tamoliv) 1000 mg IV three times daily. Diet specific for diabetes mellitus and GI problems were also administered to the patient. Patient was planned to carry out a Urea Breath Test examination, as well as nasopharyngeal swab for detection ofInfluenza AH1N1, Influenza A H5N1 and COVID-19. On the second day, laboratory result showed bicytopenia (anemia with slightly thrombocytopenia), lymphocytopenia, increased blood lipase and signs of inflammation indicated by elevated erythrocyte sedimentation rate, procalcitonin, and CRP-quantitative (Table 1).

After 2 days of admission in the hospital, on the $10^{\text {th }}$ of March 2020, the patient was referred to a national referral hospital for COVID-19 (Persahabatan Hospital). Nasopharyngeal swab results turned out to be positive and not long after the patient experienced acute respiratory distress syndrome (ARDS) which worsened and died.

\section{DISCUSSION}

COVID-19 is an emerging infectious disease caused by an evolved coronavirus. This new diseasehas yet to be properly characterised, and more importantly, no vaccines or definitive treatment for this disease have been found ${ }^{6}$. The problem also lies in the rapid spread of COVID-19, known to be more infectious than an influenza virus, thus resulting in a global spread of the disease $^{7}$.

Our patient presented with a chief complaint of profound epigastric pain with frequent episodes of vomiting on day 4 of fever, however the patient initially experienced fever and productive cough with sputum. The patient reported no travel history to places with COVID-19, which could suggest a possible local transmission. No COVID-19 specific treatment (including the recommended antiviral and hydroxychloroquine) was given to the patient in our hospital as our hospital was not a national referral hospital and resource-deficient. Laboratory test such as polymerase chain reaction (PCR) of the nasopharyngeal swab were notcarried out in our hospital as it was only available in selected hospitals and special laboratories for COVID-19.

The presentation of gastrointestinal symptoms, as found in this patient, have been previously reported in other studies before. However, the occurrence of GI symptoms was rather rare, found to be in about 5-20\% of COVID-19 patients $^{3,8,9}$.To date, no studies have explored the mortality of COVID-19 patients with and without GI symptoms. However, studies have suggested that confirmed COVID-19 patients presenting with GI symptoms were more likely to have a severe type of the disease ${ }^{3,10}$ Thus, GI symptoms presentation in this patient could indicate a severe progression of disease, leading to death.

Pre-existing comorbidities have been a known risk factor to contracting COVID-19 and are also found to aggravate the course of the disease. A meta-analysis of 46248 COVID-19 patients indicate that hypertension and diabetes were the two most prevalent comorbidities ${ }^{11}$. Furthermore, among 32 non-survivors from ICU patients with COVID-19, 22\% had diabetes ${ }^{12}$. Other studies also reported that patients with severe COVID-19 disease had hypertension and diabetes $^{9,13,14}$. Previously, chronic diseases were also found to be significantly related to severe influenza and was a major risk factor for MERS-Cov patients ${ }^{15}$, ${ }^{16}$. Our patient who presented with a severe type of COVID-19 had pre-existing Type II diabetes mellitus with signs of nephropathy (anemia, elevated blood ureum and creatinine, and decreased GFR)and chronic hypertension. Recent advances in COVID-19 research proposed that the link between chronic diseases and COVID-19 could be due to a proinflammatory state and the attenuation of innate immune response. Therefore, impairment of macrophage and lymphocyte function caused by metabolic disorders would lowering immune function ${ }^{11}$.In another view, the underlying illness could be aggravated by the 2019-nCoV. COVID-19 are found tocause extra-pulmonary organ damage such as the heart, liver, kidneys as well as the blood and immune systems leading to multiple organ failure, ARDS, shock and eventually death ${ }^{17,18}$. 
Table 1. Clinical laboratory result

\begin{tabular}{|c|c|c|c|}
\hline Clinical laboratory results & Reference range & $\begin{array}{c}\text { Hospital day } 1 \\
(08 / 03 / 20)\end{array}$ & $\begin{array}{c}\text { Hospital day } 2 \\
(09 / 03 / 20)\end{array}$ \\
\hline Hemoglobin & $13.0-17.0 \mathrm{~g} / \mathrm{dL}$ & 11.7 & 10.1 \\
\hline Hematocrite & $40.0-50.0 \mathrm{~g} / \mathrm{dL}$ & 34.2 & 28.6 \\
\hline Erythrocyte & $4.50-5.5010^{6} / \mu \mathrm{L}$ & 4.04 & 3.50 \\
\hline Mean corpuscular volume (MCV) & $83.0-101.0 \mathrm{fL}$ & 84.7 & 81.7 \\
\hline Mean corpuscular hemoglobin $(\mathrm{MCH})$ & $27.0-32.0 \mathrm{pg}$ & 29.0 & 28.9 \\
\hline $\begin{array}{l}\text { mean corpuscular hemoglobin } \\
\text { concentration }(\mathrm{MCHC})\end{array}$ & \multicolumn{2}{|c|}{ concentration (MCHC) } & 35.3 \\
\hline Thrombocyte count & $150-41010^{3} / \mu \mathrm{L}$ & 162 & 141 \\
\hline Leukocyte count & $4.00-10.0010^{3} / \mu \mathrm{L}$ & 6.95 & 4.92 \\
\hline Basophil & $0-2 \%$ & & 0 \\
\hline Eosinophil & $1-6 \%$ & & 0 \\
\hline Neutrophil & $40-80 \%$ & & 77.2 \\
\hline Lymphocyte & $20-40 \%$ & & 17.0 \\
\hline Monocyte & $2-10 \%$ & & 4.9 \\
\hline Difference & & & 0 \\
\hline Erythrocyte sedimentation rate & $0-15 \mathrm{~mm}$ & & 86 \\
\hline Procalcitonin & $<0.05 \mathrm{ng} / \mathrm{mL}$ & & 0.43 \\
\hline Pancreatic amylase & $8-51 \mathrm{U} / \mathrm{L}$ & & 46 \\
\hline Blood lipase & $8-78 \mathrm{U} / \mathrm{L}$ & & 97 \\
\hline CRP-Quantitative & $<5.0 \mathrm{mg} / \mathrm{L}$ & & 66.8 \\
\hline Aspartate aminotransferase (AST) & $5.00-34.00 \mathrm{U} / \mathrm{L}$ & 55 & \\
\hline Alanine aminotransferase (ALT) & $0.00-55.00 \mathrm{U} / \mathrm{L}$ & 50 & \\
\hline Total bilirubin & $0.2-1.2 \mathrm{mg} / \mathrm{dL}$ & 0.57 & \\
\hline Direct bilirubin & $0.0-0.5 \mathrm{mg} / \mathrm{dL}$ & 0.35 & \\
\hline Indirect bilirubin & $0.2-0.8 \mathrm{mg} / \mathrm{dL}$ & 0.22 & \\
\hline Blood creatinine & $0.73-1.18 \mathrm{mg} / \mathrm{dL}$ & 1.50 & \\
\hline Blood ureum & $18-55 \mathrm{mg} / \mathrm{dL}$ & 57.4 & \\
\hline eGFR & $79.00-117.00 \mathrm{~mL} / \mathrm{min} / 1.73 \mathrm{~m}^{2}$ & 52.0 & \\
\hline Random blood glucose & $60-140 \mathrm{mg} / \mathrm{dL}$ & 161 & \\
\hline Blood Sodium (Na+) & $136-145 \mathrm{mEq} / \mathrm{L}$ & 128 & \\
\hline Blood Potassium (K+) & $3.5-5.1 \mathrm{mEq} / \mathrm{L}$ & 4.3 & \\
\hline Blood Chloride (Cl-) & $98.0-107.0 \mathrm{mEq} / \mathrm{L}$ & 95.3 & \\
\hline \multicolumn{4}{|l|}{ Urinalysis } \\
\hline Colour & Yellow & Yellow & \\
\hline Appearance & Clear & Cloudy & \\
\hline Leukocyte & $0-5 / \mathrm{HPF}$ & $1-3$ & \\
\hline Erythrocyte & $0-2 / \mathrm{HPF}$ & $2-4$ & \\
\hline Cylinder & $0-2$ / HPF; Hyaline cylinder & Coarse granula + & \\
\hline Epithelial cells & +1 ; squamous epithelial cells & $1+$ & \\
\hline Crystals & Negative & Negative & \\
\hline Bacteria & Negative & Negative & \\
\hline Specific gravity & $1.005-1.030$ & 1.020 & \\
\hline $\mathrm{pH}$ & $4.5-8.0$ & 6.0 & \\
\hline Albumin & Negative & $3+$ & \\
\hline Glucose & Negative & Negative & \\
\hline Ketone & Negative & Negative & \\
\hline Blood/hemoglobin & Negative & Negative & \\
\hline Bilirubin & Negative & Negative & \\
\hline Urobilinogen & $3.2-16.0 \mu \mathrm{mol} / \mathrm{L}$ & 3.2 & \\
\hline Nitrite & Negative & Negative & \\
\hline Leukocyte esterase & Negative & Negative & \\
\hline
\end{tabular}

In this patient, definitive diagnosis was done through PCR of nasopharyngeal swab and no CTScan was done. The current protocol in Indonesia forconfirmation of COVID-19 case is done through nasopharyngeal swab. There have been disagreements on which methods should be used to establish a definitive diagnosis; however, it is more inclining to suggest the potential use of chest CT for diagnosing COVID-19 cases. Studies have previously reported that chest CT has a high sensitivity for diagnosing COVID-19, provides a more rapid diagnosis, and is more superior to PCR. Sensitivity of chest CT from 1014 cases in China was $97 \%{ }^{19}$. Another study reported that sensitivity of chest CT was $98 \%$ compared to RTPCR with $71 \%{ }^{20}$.
To date, no definitive treatment and management protocols for COVID-19 has been established and management is addressed symptomatically. For GI symptoms, patients were given a proton-pump inhibitor, pantoprazole, with ondansetron and domperidone. Patients were also given antimicrobials as prophylaxis for secondary infection such as meropenem and levofloxacin. For lung disease, the patient was given $\mathrm{N}$-acetylcysteine and for the fever, patient was given paracetamol. Paracetamol was given instead of ibuprofen because of several warnings saying that ibuprofen aggravates COVID-19 symptoms $^{13,21}$.

In conclusion, more information is urgently needed to understand better the course of disease of COVID-19 in order to provide better diagnosis and establish 
the most optimal treatment. Ways of reducing case fatality rates need to be further investigated, and most importantly, chain of transmissions need to be stopped to reduce the number of cases. The presentation of GIspecific symptoms as a chief complaint in COVID-19, as found in our patient, should not be overlooked. All healthcare workers should be aware of atypical presentations of this emerging disease, such as GI symptoms, as this could lead to serious implications to patients as well as healthcare providers.

\section{ACKNOWLEDGEMENT}

We would like to acknowledge the help of Dr Benny Zulkarnaien as the head of the Department of Radiology, Dr CiptoMangunkusumo Hospital, Faculty of Medicine Universitas Indonesia for the permission to access the radiologic imaging results.

\section{REFERENCES}

1. Organization WH. Coronavirus disease 2019 (COVID-19): situation report 2020.p.67.

2. Zhou F, Yu T, Du R, Fan G, Liu Y, Liu Z, et al. Clinical course and risk factors for mortality of adult inpatients with COVID-19 in Wuhan, China: a retrospective cohort study. The Lancet 2020;395:1054-62.

3. Pan L, Mu M, Ren HG, Yang P, Sun Y, Wang R. Clinical characteristics of COVID-19 patients with digestive symptoms in Hubei, China: a descriptive, cross-sectional, multicenter study. Am J Gastroenterol 2020;20.

4. Wang D, Hu B, Hu C, Zhu F, Liu X, Zhang J, et al. Clinical characteristics of 138 hospitalized patients with 2019 Novel Coronavirus-infected pneumonia in Wuhan, China. JAMA 2020;323:1061-9.

5. Holshue ML, DeBolt C, Lindquist S, Lofy KH, Wiesman J, Bruce H, et al. First case of 2019 Novel Coronavirus in the United States. New England J Med 2020;382:929-36.

6. Sanders JM, Monogue ML, Jodlowski TZ, Cutrell JB. Pharmacologic treatments for Coronavirus Disease 2019 (COVID-19): A Review. JAMA 2020;323:1824-36.

7. WHO TEAM Department of Communications. Q\&A: Similarities and differences - COVID-19 and influenza 2020 [serial online] [cited 2020 March 01]. Available from: https:// www.who.int/news-room/q-a-detail/q-a-similarities-anddifferences-covid-19-and-influenza.

8. Young BE, Ong SWX, Kalimuddin S, Low JG, Tan SY, Loh J, et al. Epidemiologic features and clinical course of patients infected with SARS-CoV-2 in Singapore. JAMA 2020;323:1488-94.

9. Guan W-j, Ni Z-y, Hu Y, Liang W-h, Ou C-q, He J-x, et al. Clinical characteristics of Coronavirus Disease 2019 in China. N Engl J Med 2020;382:1708-20.

10. Jin X, Lian J-S, Hu J-H, Gao J, Zheng L, Zhang Y-M, et al. Epidemiological, clinical and virological characteristics of 74 cases of coronavirus-infected disease 2019 (COVID-19) with gastrointestinal symptoms. Gut 2020:2020-320926.
11. Yang J, Zheng Y, Gou X, Pu K, Chen Z, Guo Q, et al. Prevalence of comorbidities in the novel Wuhan coronavirus (COVID-19) infection: a systematic review and meta-analysis. Int J Infect Dis 2020;x:X-X.

12. Yang X, Yu Y, Xu J, Shu H, Xia Ja, Liu H, et al. Clinical course and outcomes of critically ill patients with SARSCoV-2 pneumonia in Wuhan, China: a single-centered, retrospective, observational study. The Lancet Respiratory Medicine 2020;8:475-81.

13. Fang L, Karakiulakis G, Roth M. Are patients with hypertension and Diabetes mellitus at increased risk for COVID-19 infection? The Lancet Respiratory Medicine. 2020;8:e21.

14. Zhang J-j, Dong X, Cao Y-y, Yuan Y-d, Yang Y-b, Yan Y-q, et al. Clinical characteristics of 140 patients infected with SARS-CoV-2 in Wuhan, China. Allergy. 2020;x:x.

15. Hong KW, Cheong HJ, Choi WS, Lee J, Wie SH, Baek JH, et al. Clinical courses and outcomes of hospitalized adult patients with seasonal influenza in Korea, 2011-2012: Hospital-based Influenza Morbidity \& Mortality (HIMM) surveillance. J Infect Chemother 2014;20:9-14.

16. Alraddadi BM, Watson JT, Almarashi A, Abedi GR, Turkistani A, Sadran M, et al. Risk Factors for Primary Middle East Respiratory Syndrome Coronavirus Illness in Humans, Saudi Arabia, 2014. Emerg Infect Dis 2016;22:49-55.

17. Huang C, Wang Y, Li X, Ren L, Zhao J, Hu Y, et al. Clinical features of patients infected with 2019 novel coronavirus in Wuhan, China. The Lancet 2020;395:497-506.

18. Chen N, Zhou M, Dong X, Qu J, Gong F, Han Y, et al. Epidemiological and clinical characteristics of 99 cases of 2019 novel coronavirus pneumonia in Wuhan, China: a descriptive study. The Lancet 2020;395:507-13.

19. Ai T, Yang Z, Hou H, Zhan C, Chen C, Lv W, et al. Correlation of chest CT and RT-PCR testing in Coronavirus Disease 2019 (COVID-19) in China: A report of 1014 cases. Radiology 2020:200642.

20. Fang Y, Zhang H, Xie J, Lin M, Ying L, Pang P, et al. Sensitivity of chest CT for COVID-19: comparison to RTPCR. Radiology 2020:200432.

21. Day M. Covid-19: ibuprofen should not be used for managing symptoms, say doctors and scientists. BMJ 2020;368:m1086. 